\title{
Clinical Association Between Behçet Syndrome, Cytopenia, and Acquired Trisomy 8: a New Clinical Syndrome?
}

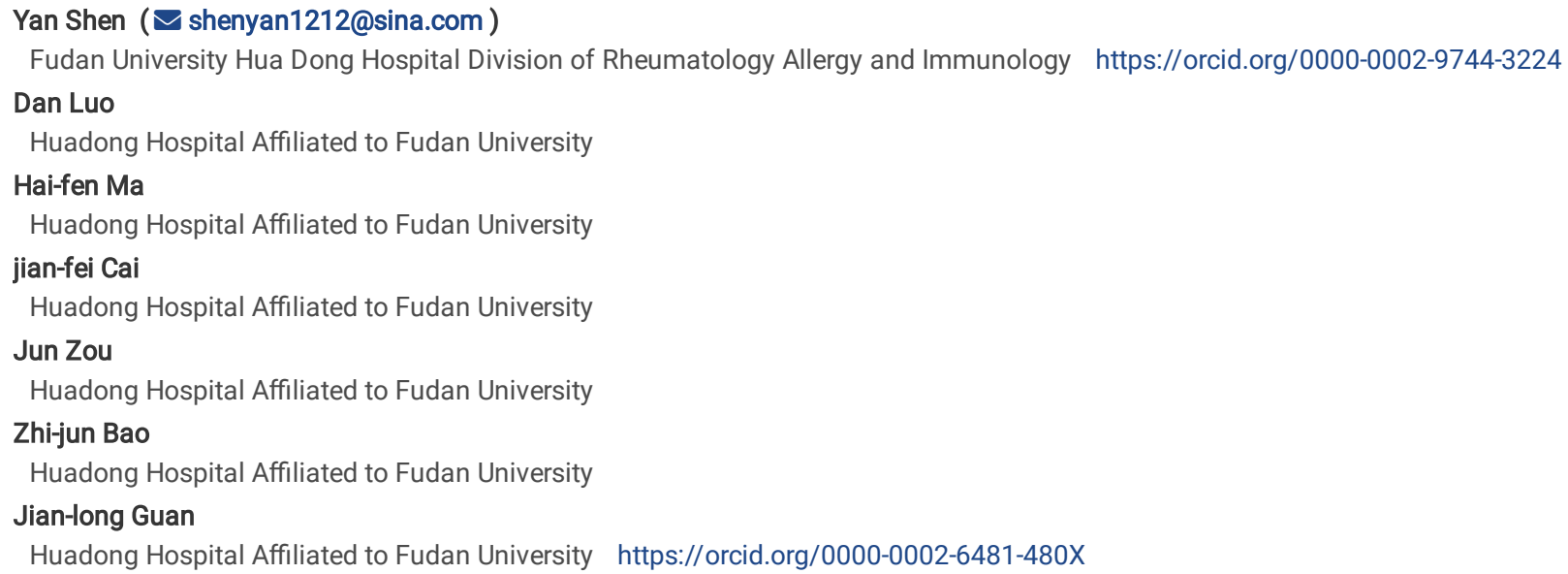




\section{Abstract}

Objectives: Behçet syndrome (BS) is heterogeneous with clinical variability across ethnicities and geographic locations. This study analyzed the clinical characteristics of BS associated with cytopenia and trisomy 8.

Methods: This was a retrospective study of Chinese BS patients in the Shanghai Behçet's disease database who were diagnosed with cytopenia and trisomy 8 between October 2012 and April 2019. All subjects fulfilled the International Study Group (ISG) criteria or the International Criteria for Behçet's Disease (ICBD).

Results: Twenty-one patients with BS had cytopenia with trisomy $8 ; 16(16 / 21,76.2 \%)$ were diagnosed with myelodysplastic syndrome (MDS). Compared with 1,147 patients with BS without cytopenia, patients with BS and trisomy $8 /$ cytopenia were more likely to be female $(23.8 \%$ vs $51.8 \%, p=0.011)$, older $(37.9 \pm$ 12.8 vs $45.1 \pm 12.0, p=0.007)$, have fewer skin lesions ( $33.3 \%$ vs $56.7 \%, p=0.033)$, fever $(52.4 \%$ vs $1.1 \%, p<0.001)$, have higher $\mathrm{C}$-reactive protein, have higher erythrocyte sedimentation rate (ESR), and display a higher rate of gastrointestinal (GI) ulceration ( $61.9 \%$ vs $9.2 \%, p<0.001)$. By contrast, they had a lower leukocyte count, lower hemoglobin levels, and a lower platelet count $(p<0.05$ for all comparisons). Ulcers in the ileocecal region were more frequently seen in intestinal patients with BS with trisomy 8 than in patients with BS without cytopenia $(100.0 \%$ vs $41.8 \% ; p=0.002)$. Compared with 54 patients with MDS without BS symptoms, those with BS and trisomy 8-cytopenia were more likely to be female $(23.8 \%$ vs $70.4 \%, p<0.001)$ and younger ( $37.9 \pm 12.8$ vs $67.2 \pm$ $12.4, p=0.001)$. In the follow-up, three patients with BS with trisomy $8(3 / 21,14.3 \%)$ died, which is a higher rate than in patients with $\mathrm{BS}(5 / 1147,0.44 \%)$ and much lower than in patients with MDS $(13 / 54,24.1 \%)$.

Conclusions: The data on patients with BS with cytopenia and trisomy 8 were different from BS or MDS in epidemiology, clinical performance, and prognosis. BS with cytopenia and acquired trisomy 8 may be a new clinical syndrome.

\section{Introduction}

Behçet syndrome (BS) is a variant of vasculitis. Its basic clinical feature is recurrent oral ulcers as an initial symptom, which is gradually associated with vulvar ulcers, nodular erythema, and other skin and mucous membrane lesions. It may be selective for ophthalmitis, intestinal ulcer, aortic regurgitation, venous thrombosis, arterial stenosis, aneurysm, arthritis, or cytopenia. BS was first comprehensively described by the dermatologist Hulusi Behçet in 1937. The disease has a high prevalence in countries along the ancient Silk Road, a route of travel and commerce extending from the eastern Mediterranean to East Asia [1].

Not much attention has been paid to changes in the blood system and rheumatism, which are common manifestations of the disease. Some diseases begin with hematological abnormalities while others occur simultaneously or successively with hematological abnormalities, which may be partially related to drug use. There has been a recent increase in the number of case reports showing an association between trisomy 8 and intestinal BS with myelodysplastic syndrome (MDS) [2, 3]. MDS is a blood disorder characterized by impaired generation and maturation of hematopoietic cells in the bone marrow, leading to peripheral blood cytopenia [4]. It may also progress into acute leukemia [4]. Previously, BS and MDS were considered two different diseases. However, there may be some connection between them since patients with MDS can develop autoimmune diseases such as BS, systemic lupus erythematosus (SLE), rheumatoid arthritis (RA), relapsing polychondritis, and vasculitis [5-8]. Indeed, most patients with BS and MDS have GI ulcers [2, 9]. It is also unclear whether immunosuppressive agents might affect this association [10].

Our team reported 16 patients with BS with MDS and found that gastrointestinal (GI) ulceration and trisomy 8 were more common in these patients [11]. In this study, we focused on patients with BS with cytopenia and trisomy 8 and investigated those patients' characteristics.

\section{Materials And Methods}

\subsection{Study Design}

This was a retrospective follow-up study of patients with BS in the Shanghai Behçet Syndrome database who had hematologic abnormalities and trisomy 8 and was diagnosed between October 2012 and April 2019. All patients had active BS and underwent endoscopic examination. This work was conducted in accordance with the Declaration of Helsinki (2000). The Institutional Review Board of Huadong Hospital approved the study protocol. The Board waived the need for individual consent.

\subsection{Patients}

During the study period, 1,168 patients with BS (with complete clinical and laboratory data) received medical care at Fudan University Huadong Hospital. All patients had active BS and were diagnosed according to the International Criteria for Behçet Disease (ICBD) [12] (the 1990 criteria were used because the 2014 criteria [13] were established during the study period). BS was diagnosed in the presence of recurrent oral ulceration and two of the following criteria: 1) recurrent genital ulceration; 2) anterior uveitis, posterior uveitis, cells in vitreous or retinal vasculitis; and 3) a positive pathergy test [12]. This retrospective study also included a cohort of 54 patients with MDS diagnosed from January 2016 to April 2020. MDS was diagnosed and classified according to the WHO classification [14], which takes into consideration morphologic, immunophenotypic, cytogenetic, fluorescence in situ hybridization (FISH), and molecular data.

\subsection{Endoscopy}

Two experienced gastroenterologists performed endoscopic examinations using GIF H260 and CF-H260A1 endoscopes (Olympus, Tokyo, Japan) for upper and lower GI tract examinations, respectively. During endoscopy, two biopsies were taken from the gastric antrum for rapid urease tests and histological examination. 


\subsection{Description of Cytopenia}

A hemoglobin count of $<13 \mathrm{~g} / \mathrm{dL}$ in men and $<12 \mathrm{~g} / \mathrm{dL}$ in women was defined as anemia, and leukocyte counts of $<4,000 / \mathrm{mm}^{3}$ ( $\geq 2$ occasions) were defined as leucopenia. Likewise, an absolute neutrophil count of $<1,500 / \mathrm{mm}^{3}$ ( $\geq 2$ occasions) was defined as neutropenia, and a platelet (PLT) count of $<$ $100,000 / \mathrm{mm}^{3}$ was defined as thrombocytopenia. The presence of any such values was acknowledged as meeting the criteria for cytopenia.

\subsection{Cytogenetics}

Bone marrow chromosome analysis was performed using chromosome-banding procedures. At least 20 metaphases were analyzed. Abnormal clones were described according to the 2006 International System for Human Cytogenetic Nomenclature (ISCN) [15], and aberrations were counted following the International Working Group on MDS Cytogenetics (IWGMC) consensus guidelines [16]. FISH analysis was performed on short-term cultured bone marrow. Sample preparations and hybridizations were performed according to the manufacturer's recommendations, using commercially available probes (Vysis Inc., Downers Grove, IL, USA). At our hospital, systematic screening for trisomy 8 was performed on patients with BS with hemocytosis. Karyotyping was performed on these patients based on clinical suspicion of trisomy 8 . Blood marrow aspiration was done to perform karyotyping, and a minimum of 500 interphase cells were analyzed. If the cells with an abnormal signal were $<5 \%, 1,000$ interphase cells were screened. Normal control values were previously established using five normal samples of bone marrow donors and 15 bone marrow samples of patients with iron deficiency anemia but with normal karyotype.

\subsection{Clinical Evaluation and Laboratory Findings}

The presence of GI symptoms, such as abdominal pain, melena/hematochezia, diarrhea, weight loss, perforation, ileus, or bleeding, and extra-GI symptoms, such as genital ulcers, uveitis, dermatological lesions, neurological involvement, peripheral vasculitis, and joint involvement, were recorded at the time of diagnosis. Erythrocyte sedimentation rate (ESR), C-reactive protein (CRP) level, and peripheral blood counts were also recorded.

\subsection{Statistical Analysis}

Continuous data were tested for normal distribution using the Kolmogorov-Smirnov test. Normally distributed continuous data were presented using mean \pm standard deviation and analyzed using Student's $t$-test. Nonnormally distributed data were presented as a median (range) and analyzed using the MannWhitney $\mathrm{U}$ test. Categorical data were presented as frequencies and analyzed using the chi-squared test or Fisher's exact test, as appropriate. Factors found to be significantly different between the groups were integrated into a logistic regression model to identify independently associated factors for hematologic abnormality development. SPSS 22.0 (IBM Corp., Armonk, NY, USA) was used for statistical analyses. Two-sided $p$-values $<0.05$ were considered statistically significant.

\section{Results}

\subsection{Patient Characteristics}

Of the 1,168 patients with BS, there were 21 with BS and trisomy 8 and 1,147 with BS without trisomy 8 . One female with BS presented with MDS and cervical cancer. Among the 21 patients with BS with cytopenia, 16 were diagnosed with MDS (76.2\%). BS was diagnosed before hematologic abnormality in eight (38.1\%) patients, after hematologic abnormality in six (28.6\%), and concomitantly with hematologic abnormality in seven (33.3\%) (Table 1 ). 
Table 1

Clinical characteristics of 21 patients with Behçet disease and hematologic disorder.

\begin{tabular}{|c|c|c|c|c|c|c|c|c|c|c|}
\hline $\begin{array}{l}\text { Case } \\
\text { No. }\end{array}$ & Age/sex & $\begin{array}{l}\text { BD } \\
\text { symptoms }\end{array}$ & MDS type & Karyotype and FISH & $\begin{array}{l}\text { Endoscopic } \\
\text { findings }\end{array}$ & $\begin{array}{l}\text { Distribution } \\
\text { pattern }\end{array}$ & $\begin{array}{l}\text { BD } \\
\text { duration } \\
\text { (years) }\end{array}$ & $\begin{array}{l}\text { MDS } \\
\text { duration } \\
\text { (years) }\end{array}$ & Treatment & $\begin{array}{l}\text { Cytoto } \\
\text { prior tc }\end{array}$ \\
\hline 1 & $47 / F$ & IOGA & MDS-RCMD & $47 X X+8$ & $\begin{array}{l}\text { Terminal } \\
\text { ileum, } \\
\text { rectum, CU }\end{array}$ & $\begin{array}{l}\text { Multi- } \\
\text { segmental }\end{array}$ & 20 & 20 & $\begin{array}{l}\text { Prednisone } \\
\text { Cyclosporine } \\
\text { Thalidomide } \\
\text { Infliximab }\end{array}$ & - \\
\hline 2 & $35 / F$ & IOGS & MDS-U & $47 X X+8$ & $\begin{array}{l}\text { Terminal } \\
\text { ileum }\end{array}$ & $\begin{array}{l}\text { Multi- } \\
\text { segmental }\end{array}$ & 6 & 10 & $\begin{array}{l}\text { Prednisone } \\
\text { Cyclosporine } \\
\text { Thalidomide } \\
\text { Infliximab }\end{array}$ & - \\
\hline 3 & $35 / \mathrm{M}$ & IOG & MDS-U & $47 X X+8$ & $\begin{array}{l}\text { Terminal } \\
\text { ileum }\end{array}$ & Single & 5 & 1 & $\begin{array}{l}\text { Prednisone } \\
\text { Infliximab }\end{array}$ & $\begin{array}{l}\text { Cyclos } \\
\text { Thalidı }\end{array}$ \\
\hline 4 & $68 / F$ & IOSA & Anemia & $47 X X+8$ & $\begin{array}{l}\text { Terminal } \\
\text { ileum, } \\
\text { ileocecal } \\
\text { valve }\end{array}$ & $\begin{array}{l}\text { Multi- } \\
\text { segmental }\end{array}$ & 40 & 1 & $\begin{array}{l}\text { Prednisone } \\
\text { Cyclosporine } \\
\text { Infliximab }\end{array}$ & $\begin{array}{l}\text { MMF } \\
\text { Thalidı }\end{array}$ \\
\hline 5 & $46 / F$ & IOGPA & MDS-U & $47 X X+8$ & $\begin{array}{l}\text { lleocecal } \\
\text { valve }\end{array}$ & Single & 10 & 10 & $\begin{array}{l}\text { Prednisone } \\
\text { Cyclosporine } \\
\text { Thalidomide } \\
\text { Infliximab }\end{array}$ & - \\
\hline 6 & $65 / M$ & IOG & MDS-RAEB & $\begin{array}{l}48, X Y,+8,+19, \operatorname{del}(20) \\
\text { (q11.2) }\end{array}$ & $\begin{array}{l}\text { Terminal } \\
\text { ileum, CU }\end{array}$ & $\begin{array}{l}\text { Multi- } \\
\text { segmental }\end{array}$ & 5 & 0.5 & $\begin{array}{l}\text { Prednisone } \\
\text { Cyclosporine } \\
\text { Thalidomide } \\
\text { Infliximab }\end{array}$ & - \\
\hline 7 & $56 / F$ & IOPS & MDS-RCUD-RN & $47 X X+8$ & $\begin{array}{l}\text { lleocecal } \\
\text { valve }\end{array}$ & Single & 14 & 20 & $\begin{array}{l}\text { Prednisone } \\
\text { Cyclosporine } \\
\text { Thalidomide } \\
\text { Infliximab }\end{array}$ & - \\
\hline 8 & $58 / F$ & IOGS & MDS-RCMD & $47 X X+8$ & $\begin{array}{l}\text { Terminal } \\
\text { ileum, } \\
\text { CU,small } \\
\text { intestine }\end{array}$ & $\begin{array}{l}\text { Multi- } \\
\text { segmental }\end{array}$ & 36 & 20 & $\begin{array}{l}\text { Prednisone } \\
\text { Cyclosporine } \\
\text { Infliximab }\end{array}$ & Thalidı \\
\hline 9 & $48 / F$ & IOGP & MDS-RCMD & $47 X X+8$ & $\begin{array}{l}\text { lleocecal } \\
\text { valve }\end{array}$ & Single & 8 & 7 & $\begin{array}{l}\text { Prednisone } \\
\text { Cyclosporine } \\
\text { Thalidomide } \\
\text { Infliximab }\end{array}$ & - \\
\hline 10 & $34 / F$ & IOG & MDS-RCUD & $\begin{array}{l}47 X X+ \\
8,-20, \operatorname{add}(21)(q 21)\end{array}$ & $\begin{array}{l}\text { Terminal } \\
\text { ileum, CU }\end{array}$ & $\begin{array}{l}\text { Multi- } \\
\text { segmental }\end{array}$ & 4 & 4 & $\begin{array}{l}\text { Prednisone } \\
\text { Cyclosporine } \\
\text { Thalidomide } \\
\text { Infliximab }\end{array}$ & - \\
\hline 11 & $36 / F$ & OG & Leucopenia & $47 X X+8$ & - & - & 4 & 10 & $\begin{array}{l}\text { Thalidomid } \\
\text { Colchicine }\end{array}$ & - \\
\hline 12 & $44 / F$ & OGP & MDS-U & $47 X X+8$ & - & - & 10 & 20 & $\begin{array}{l}\text { Thalidomid } \\
\text { Colchicine }\end{array}$ & - \\
\hline
\end{tabular}

I: Intestinal involvement; O: oral ulcer; G: genital ulcer; S: skin lesion; A: arthritis; P: pathergy. MDS-U: MDS-unclassifiable, RCMD: refractory cytopenia with mu RAEB: refractory anemia with excess of blasts, RCUD: refractory cytopenia with unilineage dysplasia. CU: colonic ulcers. MMF: mycophenolate mofetil. 


\begin{tabular}{|c|c|c|c|c|c|c|c|c|c|c|}
\hline $\begin{array}{l}\text { Case } \\
\text { No. }\end{array}$ & Age/sex & $\begin{array}{l}\text { BD } \\
\text { symptoms }\end{array}$ & MDS type & Karyotype and FISH & $\begin{array}{l}\text { Endoscopic } \\
\text { findings }\end{array}$ & $\begin{array}{l}\text { Distribution } \\
\text { pattern }\end{array}$ & $\begin{array}{l}\text { BD } \\
\text { duration } \\
\text { (years) }\end{array}$ & $\begin{array}{l}\text { MDS } \\
\text { duration } \\
\text { (years) }\end{array}$ & Treatment & $\begin{array}{l}\text { Cytoto } \\
\text { prior tc }\end{array}$ \\
\hline 13 & $40 / \mathrm{F}$ & OG & $\begin{array}{l}\text { Leucopenia + } \\
\text { thrombocytopenia }\end{array}$ & $47 X X+8$ & - & - & 10 & 10 & $\begin{array}{l}\text { Cyclosporine } \\
\text { Thalidomid }\end{array}$ & - \\
\hline 14 & $59 / \mathrm{M}$ & OGA & MDS-U & $47 X X+8$ & - & - & 10 & 1 & $\begin{array}{l}\text { Prednisone } \\
\text { Cyclosporine } \\
\text { Thalidomide }\end{array}$ & - \\
\hline 15 & $30 / F$ & IOGS & $\begin{array}{l}\text { Leucopenia }+ \\
\text { thrombocytopenia }\end{array}$ & $47 X X+8$ & $\begin{array}{l}\text { Terminal } \\
\text { ileum }\end{array}$ & Single & 5 & 5 & $\begin{array}{l}\text { Prednisone } \\
\text { Cyclosporine } \\
\text { Thalidomide } \\
\text { Infliximab }\end{array}$ & Thalidı \\
\hline 16 & $42 / F$ & OGS & MDS-RAEB & $47 X X+8$ & - & - & 3 & 5 & $\begin{array}{l}\text { Prednisone } \\
\text { Cyclosporine } \\
\text { Thalidomide }\end{array}$ & - \\
\hline 17 & $46 / F$ & OGS & MDS-RAEB & $47 X X+8$ & - & - & 10 & 1 & $\begin{array}{l}\text { Prednisone } \\
\text { Cyclosporine } \\
\text { Thalidomide }\end{array}$ & - \\
\hline 18 & $25 / F$ & OG & MDS- RCMD & $47 X X+8$ & - & - & 10 & 10 & $\begin{array}{l}\text { Prednisone } \\
\text { Cyclosporine } \\
\text { Thalidomide }\end{array}$ & - \\
\hline 19 & $52 / \mathrm{M}$ & IOG & MDS-U & $47 X Y+8$ & $\begin{array}{l}\text { Terminal } \\
\text { ileum, CU }\end{array}$ & $\begin{array}{l}\text { Multi- } \\
\text { segmental }\end{array}$ & 7 & 2 & $\begin{array}{l}\text { Prednisone } \\
\text { Cyclosporine } \\
\text { Thalidomide } \\
\text { Infliximab } \\
\text { Tocilizumab }\end{array}$ & Thalid, \\
\hline 20 & $56 / F$ & IOA & MDS-RCMD & $48 X X+8+9$ & $\begin{array}{l}\text { Terminal } \\
\text { ileum, } \\
\text { small } \\
\text { intestine }\end{array}$ & $\begin{array}{l}\text { Multi- } \\
\text { segmental }\end{array}$ & 5 & 0.5 & $\begin{array}{l}\text { Prednisone } \\
\text { Cyclosporine } \\
\text { Thalidomide } \\
\text { Tocilizumab }\end{array}$ & - \\
\hline 21 & $39 / M$ & OGP & $\begin{array}{l}\text { Leucopenia + } \\
\text { thrombocytopenia }\end{array}$ & $47 X X+8 / 46 X Y$ & - & - & 10 & 7 & Thalidomide & - \\
\hline
\end{tabular}

All patients were clinically and cytogenetically evaluated once when BS was active, with or without treatment. Based on the WHO classification, six patients had MDS-unclassifiable (MDS-U), five had refractory cytopenia with multilineage dysplasia (RCMD), three had refractory anemia with excess of blasts (RAEB), and two had refractory cytopenia with unilinear dysplasia (RCUD). Among the other five patients with undiagnosed MDS, one had anemia, one had leucopenia, and three had leucopenia and thrombocytopenia.

\subsection{Clinical Features of MDS, BS with Trisomy 8 , and BS without Trisomy 8}

Table 2 shows the demographic and clinical features of patients with BS, BS with trisomy 8 , and MDS. Among the 21 patients, five were male and 16 were female. The mean age at diagnosis was $37.9 \pm 12.6$ years for BS, $45.1 \pm 12.0$ years for BS with trisomy 8 , and $67.2 \pm 12.4$ years MDS. There were great differences in gender and age between the three groups $(p<0.05)$. 
Clinical characteristics between BS patients and BS with/without hematologic disorder and trisomy 8 and MDS patients.

\begin{tabular}{|c|c|c|c|}
\hline & $\begin{array}{l}\text { BS with hematologic disorder and trisomy } 8 \\
(n=21)\end{array}$ & $\begin{array}{l}\text { BS without hematologic disorder and trisomy } 8 \\
(n=1147)\end{array}$ & $\begin{array}{l}\text { MDS } \\
(n=54)\end{array}$ \\
\hline Age, years mean (SD) & $45.1 \pm 12.0^{*}$ & $37.9 \pm 12.8$ & $67.2 \pm 12.4^{* \star}$ \\
\hline Male (\%) & $5(23.8)$ * & $594(51.8)$ & $38(70.4)$ ** \\
\hline Oral ulcer & $21(100)$ & 1051 (91.6) & - \\
\hline Genital ulcer & $18(85.7)$ & $796(69.4)$ & - \\
\hline Ocular lesion & $0(0)$ & $157(13.7)$ & - \\
\hline Arthritis & $6(28.6)$ & $243(21.2)$ & - \\
\hline Skin lesions & $7(33.3)$ * & $650(56.7)$ & - \\
\hline Positive pathergy test & $5(23.8)$ & $55 / 125(44.0)$ & - \\
\hline Central nervous system & $1(4.8)$ & $18(1.6)$ & - \\
\hline Vascular lesions & $0(0)$ & $35(3.1)$ & - \\
\hline GI involvement & $13(61.9)$ * & $110(9.2)$ & $0(0) * *$ \\
\hline Fever & $11(52.4)$ * & $13(1.1)$ & $10(18.5)$ ** \\
\hline \multicolumn{4}{|c|}{ Laboratory findings at diagnosis of BS or MDS } \\
\hline $\operatorname{ESR}(\mathrm{mm} / \mathrm{h})$ & $52.7 \pm 33.9 *$ & $22.1 \pm 24.4$ & \\
\hline CRP (mg/L) & $34.9 \pm 34.5^{\star}$ & $12.9 \pm 21.5$ & \\
\hline WBC $\left(10^{9} / \mathrm{L}\right)$ & $3.2 \pm 1.2^{\star}$ & $7.4 \pm 2.5$ & \\
\hline Hemoglobin (g/L) & $99.4 \pm 18.8^{*}$ & $132.4 \pm 19.4$ & \\
\hline Platelets $\left(10^{9} / \mathrm{L}\right)$ & $52.7 \pm 33.9 *$ & $240.1 \pm 72.8$ & \\
\hline \multicolumn{4}{|c|}{${ }^{*} \mathrm{P}<0.05$. BS with hematologic disorder and trisomy 8 compared to BS. } \\
\hline \multicolumn{4}{|c|}{ ** $\mathrm{P}<0.05$. BS with hematologic disorder and trisomy 8 compared to MDS. } \\
\hline
\end{tabular}

In the BS with trisomy 8 group, oral ulcers were the most common finding (100\%), followed by genital ulcers (87.5\%), GI involvement (61.9\%), fever (52.4\%), and skin lesions (33.3\%). Uveitis and vascular lesions, which are common features of BS, were not recorded in the BS with trisomy 8 group. In the univariate analyses, BS with trisomy 8 patients were significantly more likely to be female, older, have a fever, display GI involvement, and have fewer skin lesions than patients with BS without trisomy $8(p<0.01)$ (Table 2). Leukocyte count, hemoglobin levels, and platelet count were significantly lower, and ESR and CRP significantly higher, in BS with trisomy 8 patients than in those with BS without trisomy $8(p<0.05)$.

\subsection{Characteristics of Patients with BS with or without Trisomy 8 in GI Involvement}

Among the 1,147 patients with BS, 110 had GI BS without cytopenia, and 13 had GI BS with cytopenia and trisomy 8 . Table 3 shows the demographic and clinical features of the two groups. In patients with GI BS and trisomy 8 , oral ulcers were the most common finding (100\%), followed by genital ulcers ( $80.0 \%$ ), fever $(60.0 \%)$, skin lesions $(40.0 \%)$, positive pathergy tests $(30.0 \%)$, and arthralgia (30.0\%). Patients with GI BS and trisomy 8 were significantly more likely to have intestinal ulcers in the ileocecal region than patients with BS with GI without MDS ( $100.0 \%$ vs $48.9 \%$; $p=0.032)$. Figure 1 shows the typical colonoscopy results of patients with GI BS and trisomy 8 . In the univariate analyses, patients with GI BS and trisomy 8 were more likely to be female and older than patients with GI BS but no trisomy $8(p<0.01)$ (Table 3$)$. The former were likely to have a lower leukocyte count, hemoglobin level, and platelet count, and higher ESR levels, than the latter $(p<0.05)$. There was no statistically significant difference in GI symptoms and CRP level between the two groups. 
Table 3

Symptoms and laboratory findings in patients with intestinal BS according to hematologic abnormality and trisomy 8

\begin{tabular}{|c|c|c|c|}
\hline & $\begin{array}{l}\text { Intestinal BS with hematologic abnormality } \\
\text { trisomy } 8 \\
(n=13)\end{array}$ & $\begin{array}{l}\text { Intestinal BS without hematologic abnormality } \\
(n=110)\end{array}$ & $\mathbf{P}$ \\
\hline $\begin{array}{l}\text { Age at diagnosis of intestinal BS } \\
\text { (years) }\end{array}$ & $48.3 \pm 12.4$ & $36.5 \pm 15.1$ & $0.008^{*}$ \\
\hline Male (\%) & $3(23.1)$ & $58(52.7)$ & $0.041^{*}$ \\
\hline Duration (years) & $10.2 \pm 9.5$ & $9.3 \pm 9.2$ & 0.129 \\
\hline \multicolumn{4}{|l|}{ Systemic signs } \\
\hline Oral ulcer & $13(100)$ & $108(98.2)$ & $>0.99$ \\
\hline Genital ulcer & $11(84.6)$ & $69(62.7)$ & 0.708 \\
\hline Ocular lesion & $0(0)$ & $3(3.2)$ & $>0.99$ \\
\hline Arthralgia & $3(23.1)$ & $22(23.4)$ & 0.694 \\
\hline Skin lesions & $4(30.8)$ & $42(44.7)$ & $>0.99$ \\
\hline Positive pathergy test & $3(23.1)$ & $20(21.3)$ & 0.608 \\
\hline Central nervous system & $0(0)$ & $1(0)$ & - \\
\hline \multicolumn{4}{|l|}{ Symptoms of GI involvement } \\
\hline Abdominal pain & $8(61.5)$ & $82(87.2)$ & 0.184 \\
\hline Melena/hematochezia & $4(30.8)$ & $30(31.9)$ & 0.717 \\
\hline Diarrhea & $5(38.5)$ & $46(48.9)$ & $>0.99$ \\
\hline Weight loss & $8(61.5)$ & $44(46.8)$ & 0.083 \\
\hline Fever & $9(69.2)$ & $8(8.5)$ & $0.002^{*}$ \\
\hline Perforation & $0(0)$ & $8(8.5)$ & $>0.99$ \\
\hline lleus & $1(7.7)$ & $8(8.5)$ & $>0.99$ \\
\hline \multicolumn{4}{|l|}{ Location of intestinal ulcers } \\
\hline Esophagus & $0(0)$ & $18(19.1)$ & 0.336 \\
\hline Ileocecal & $13(100)$ & $46(41.8)$ & $0.002^{*}$ \\
\hline Small intestine & $1(7.7)$ & $6(6.4)$ & 0.548 \\
\hline Colon & $1(7.7)$ & $24(25.5)$ & 0.426 \\
\hline \multicolumn{4}{|l|}{ Laboratory findings at BS diagnosis } \\
\hline $\operatorname{ESR}(\mathrm{mm} / \mathrm{h})$ & $51.14 \pm 31.19$ & $26.78 \pm 23.64$ & $0.005^{*}$ \\
\hline CRP (mg/L) & $29.03 \pm 33.53$ & $21.21 \pm 33.07$ & 0.327 \\
\hline WBC $\left(10^{9} / \mathrm{L}\right)$ & $3.7 \pm 2.5$ & $6.8 \pm 2.9$ & $0.003^{*}$ \\
\hline Hemoglobin (g/L) & $89.7 \pm 17.7$ & $129.4 \pm 19.9$ & $\begin{array}{l}<.001 * \\
0.01 *\end{array}$ \\
\hline Platelets $\left(10^{9} / \mathrm{L}\right)$ & $163.9 \pm 116.4$ & $243.1 \pm 92.7$ & $\begin{array}{l}<.001 * \\
0.01\end{array}$ \\
\hline
\end{tabular}

\subsection{Treatment and Outcome of BS with Cytopenia and Trisomy 8}

Overall, 21/21 (100\%) patients with BS with trisomy 8 had received treatment, 17 (81.0\%) with steroids (prednisone, median dose $30 \mathrm{mg} / \mathrm{day}$ [IQR 20-48]). Along with steroids, the immunosuppressive drugs that were used included thalidomide $(n=18)$, cyclosporine $(n=17)$, infliximab $(n=11)$, and colchicine $(n=$ 2). In a median follow-up of 37 months (range, 17 to 72 months), 3/21 (33.3\%) cases showed complete responses to first-cycle therapy (about three months) and achieved clinical improvements for BS and hematologic abnormalities. Meanwhile, $2 / 21$ (9.5\%) cases showed no improvement, not only in BS but also in hematologic abnormality. Several cases $(14 / 21 ; 66.7 \%)$ showed stability in BS and cytopenia. In total, $3 / 21$ (mortality rate: $14.3 \%)$ patients died during followup: one from infectious complications, one from hematological complications, and one with an undetermined cause of death. From the follow-up data, three 
patients with BS with trisomy $8(3 / 21,14.3 \%)$ died, which is a much higher rate than patients with BS $(5 / 1147,0.44 \%)$ and much lower than patients with MDS $(13 / 54,24.1 \%)(p<0.01)$.

\section{Discussion}

In this retrospective study, we focused on a unique group of patients with BS that had a prominent feature of cytopenia and trisomy 8 . This study is the first to report on patients with BS with trisomy 8 from the Shanghai Behçet Syndrome Database. In terms of gender and age, patients with BS with cytopenia and trisomy 8 were more likely to be female and older than patients with BS and much younger than patients with MDS. The incidence of gastrointestinal (GI) ulceration was much higher than in BS and patients with MDS, and ulcers in the ileocecal region were more frequently seen in intestinal patients with BS and trisomy 8. More than half of the patients were diagnosed with MDS. The mortality rates of BS patients with trisomy 8 were different from those of BS and MDS patients, which were much higher than those of patients with BS and much lower than those of patients with MDS.

BS is a complex, multisystemic disorder with unknown etiology and unique geographic distribution. There has been controversy over whether to call it a "disease" or "syndrome." Many studies have shown that it is composed of multiple phenotypes, such as skin-mucosa, eye, gastrointestinal, vascular, and neurological involvement [17]. Hematologic involvement or hematologic malignancies are frequently encountered in rheumatic diseases, such as systemic lupus erythematosus (SLE) and Sjögren syndrome (SS) [18]. Until now, however, no paper has reported hematologic involvement as a particular phenotype in BS, and there has been little research on hematologic involvement in large BS samples. Some studies have even referred to it as a "Behçet-like disease" [19, 20]. Analyses of several case reports have shown an association between trisomy 8 and intestinal BD with MDS [2, 3, 21, 22]. Indeed, trisomy 8 in BD and MDS has been reported in $87 \%$ of patients [2], compared to $5-7 \%$ of patients with primary MDS but without BD [23]. Trisomy 8 with BD but without MDS has also been reported $[24,25]$.

Trisomy 8 is considered a secondary or late event in the MDS transformation process [26, 27]. The precise mechanisms underlying the tumorigenesis remain unclear, although a relationship has been observed between trisomy 8 and symptoms related to BD, both in the present study and in the literature. As BD-MDS patients have high frequencies of intestinal lesions and trisomy 8 , as well as a higher expression of several cytokines controlled by genes located on chromosome 8 , trisomy 8 may predispose patients with cytopenia to BD.

According to our data, most of the BS with trisomy 8 /cytopenia patients were isolated trisomy 8 (19/21, 90.5\%). Some patients lacking morphological criteria in the bone marrow were not considered as patients with MDS. Isolated trisomy 8 has been discussed in some studies [28, 29]. It can be a constitutional condition as a constitutional mosaicism (cT8M) in healthy people, and it was not considered a tumor marker in certain studies. Some studies have suggested that trisomy 8 could be present as a cT8M in myeloid malignancies. In our retrospective study, we found that BS associated with trisomy $8 /$ cytopenia had a particular clinical phenotype, mainly represented by frequent gastrointestinal involvement, less ocular and central neurological impairment, and unique characteristics in terms of gender, age, and survival rate. We suggest that BS with cytopenia and trisomy 8 could be a new entity characterized by ulcerative gastrointestinal involvement. Newer genomic technologies, such as single-nucleotide polymorphism array and next-generation sequencing, may reveal the heterozygous deletions resulting in haploin sufficient gene expression involved in the pathogenesis of these GI-BS patients with trisomy 8 .

\section{Conclusion}

BS with trisomy 8 can be associated with a particular phenotype of ulcerative digestive disease, which has unique characteristics in terms of gender, age, and survival rate. Thus, it should be considered a distinct disease. Differential diagnosis may sometimes be difficult. Further studies are needed to determine the role of overexpressed trisomy 8 genes, identify the underlying mechanisms, and determine the best treatment regimen.

\section{Declarations}

\section{Conflicts of interest}

The authors declare that there are no conflicts of interest regarding the publication of this article.

\section{Funding}

The study was supported by the National Natural Science Foundation of China (no. 81871276), the Clinical Science Innovation Program of Shanghai Shenkang Hospital Development Center (SHDC1207129), and the Shanghai Pujiang Young Rheumatologists Training Program (SPROG201803).

\section{References}

1. Sakane T, Takeno M, Suzuki N, Inaba G: Behcet's disease. N Engl J Med 1999, 341(17):1284-1291.

2. Tada Y, Koarada S, Haruta Y, Mitamura M, Ohta A, Nagasawa K: The association of Behcet's disease with myelodysplastic syndrome in Japan: a review of the literature. Clin Exp Rheumatol 2006, 24(5 Suppl 42):S115-119.

3. Kawabata H, Sawaki T, Kawanami T, Shimoyama K, Karasawa H, Fukushima T, Masaki Y, Ogawa N, Hirose Y, Ozaki K et al: Myelodysplastic syndrome complicated with inflammatory intestinal ulcers: significance of trisomy 8. Intern Med 2006, 45(22):1309-1314.

4. Garcia-Manero G: Myelodysplastic syndromes: 2014 update on diagnosis, risk-stratification, and management. Am J Hematol 2014, 89(1):97-108. 
5. Okamoto T, Okada M, Mori A, Saheki K, Takatsuka H, Wada H, Tamura A, Fujimori Y, Takemoto Y, Kanamaru A et al: Correlation between immunological abnormalities and prognosis in myelodysplastic syndrome patients. Int J Hematol 1997, 66(3):345-351.

6. Marisavljevic D, Kraguljac N, Rolovic Z: Immunologic abnormalities in myelodysplastic syndromes: clinical features and characteristics of the lymphoid population. Med Oncol 2006, 23(3):385-391.

7. Giannouli S, Voulgarelis M, Zintzaras E, Tzioufas AG, Moutsopoulos HM: Autoimmune phenomena in myelodysplastic syndromes: a 4-yr prospective study. Rheumatology (Oxford) 2004, 43(5):626-632.

8. de Hollanda A, Beucher A, Henrion D, Ghali A, Lavigne C, Levesque H, Hamidou M, Subra JF, Ifrah N, Belizna C: Systemic and immune manifestations in myelodysplasia: a multicenter retrospective study. Arthritis Care Res (Hoboken) 2011, 63(8):1188-1194.

9. Kimura S, Kuroda J, Akaogi T, Hayashi H, Kobayashi Y, Kondo M: Trisomy 8 involved in myelodysplastic syndromes as a risk factor for intestinal ulcers and thrombosis-Behcet's syndrome. Leuk Lymphoma 2001, 42(1-2):115-121.

10. Papageorgiou A, Ziakas PD, Tzioufas AG, Voulgarelis M: Indications for bone marrow examination in autoimmune disorders with concurrent haematologic alterations. Clin Exp Rheumatol 2013, 31(1):76-83.

11. Shen Y, Ma HF, Luo D, Cai JF, Zou J, Guan JL: High Incidence of Gastrointestinal Ulceration and Cytogenetic Aberration of Trisomy 8 as Typical Features of Behcet's Disease Associated with Myelodysplastic Syndrome: A Series of 16 Consecutive Chinese Patients from the Shanghai Behcet's Disease Database and Comparison with the Literature. Biomed Res Int 2018, 2018:8535091.

12. Criteria for diagnosis of Behcet's disease. Intemational Study Group for Behcet's Disease. Lancet 1990, 335(8697):1078-1080.

13. The International Criteria for Behcet's Disease (ICBD): a collaborative study of 27 countries on the sensitivity and specificity of the new criteria. $J$ Eur Acad Dermatol Venereol 2014, 28(3):338-347.

14. Vardiman J: The classification of MDS: from FAB to WHO and beyond. Leuk Res 2012, 36(12):1453-1458.

15. Gonzalez Garcia JR, Meza-Espinoza JP: Use of the International System for Human Cytogenetic Nomenclature (ISCN). Blood 2006, 108(12):3952-3953; author reply 3953.

16. Chun K, Hagemeijer A, lqbal A, Slovak ML: Implementation of standardized international karyotype scoring practices is needed to provide uniform and systematic evaluation for patients with myelodysplastic syndrome using IPSS criteria: An International Working Group on MDS Cytogenetics Study. Leuk Res 2010, 34(2):160-165.

17. Seyahi E: Phenotypes in Behcet's syndrome. Intern Emerg Med 2019, 14(5):677-689.

18. Nikolopoulos D, Adamichou C, Bertsias G: Suspected systemic meumatic diseases in patients presenting with cytopenias. Best Pract Res Clin Rheumatol 2019, 33(4):101425.

19. Wesner N, Drevon L, Guedon A, Fraison JB, Terrier B, Trad S, Kahn JE, Aouba A, Gillard J, Ponsoye M et al: Gastrointestinal Behcet's-like disease with myelodysplastic neoplasms with trisomy 8: a French case series and literature review. Leuk Lymphoma 2019, 60(7):1782-1788.

20. Wesner N, Drevon L, Guedon A, Fraison JB, Trad S, Kahn JE, Aouba A, Gillard J, Ponsoye M, Hanslik T et al: Inflammatory disorders associated with trisomy 8-myelodysplastic syndromes: French retrospective case-control study. Eur J Haematol 2019, 102(1):63-69.

21. Ahn JK, Cha HS, Koh EM, Kim SH, Kim YG, Lee CK, Yoo B: Behcet's disease associated with bone marrow failure in Korean patients: clinical characteristics and the association of intestinal ulceration and trisomy 8. Rheumatology (Oxford) 2008, 47(8):1228-1230.

22. Esatoglu SN, Hatemi G, Salihoglu A, Hatemi I, Soysal T, Celik AF: A reappraisal of the association between Behcet's disease, myelodysplastic syndrome and the presence of trisomy 8: a systematic literature review. Clin Exp Rheumato/ 2015, 33(6 Suppl 94):S145-151.

23. Hosono N: Genetic abnormalities and pathophysiology of MDS. Int J Clin Oncol 2019, 24(8):885-892.

24. Mora P, Avellis FO, Zavota L, Orsoni JG: Behcet's disease associated with trisomy 8 in a young Italian girl-a case report. Clin Exp Rheumato/ 2008, 26(4):706.

25. Becker K, Fitzgerald O, Green AJ, Keogan M, Newbury-Ecob R, Greenhalgh L, Withers S, Hollox EJ, Aldred PM, Armour JA: Constitutional trisomy 8 and Behcet syndrome. Am J Med Genet A 2009, 149A(5):982-986.

26. Nilsson L, Astrand-Grundstrom I, Anderson K, Arvidsson I, Hokland P, Bryder D, Kjeldsen L, Johansson B, Hellstrom-Lindberg E, Hast R et al: Involvement and functional impairment of the CD34(+)CD38(-)Thy-1(+) hematopoietic stem cell pool in myelodysplastic syndromes with trisomy 8 . Blood 2002, 100(1):259-267.

27. de Souza Fernandez T, Ornellas MH, Otero de Carvalho L, Tabak D, Abdelhay E: Chromosomal alterations associated with evolution from myelodysplastic syndrome to acute myeloid leukemia. Leuk Res 2000, 24(10):839-848.

28. Saumell S, Sole F, Arenillas L, Montoro J, Valcarcel D, Pedro C, Sanzo C, Luno E, Gimenez T, Arnan M et al: Trisomy 8, a Cytogenetic Abnormality in Myelodysplastic Syndromes, Is Constitutional or Not? PLoS One 2015, 10(6):e0129375.

29. Salihoglu A, Soysal T: Trisomy-8-Positive Hematologic Malignancies Associated with Intestinal Behcet's Syndrome: Keep This Entity in Mind. Acta Haematol 2020, 143(3):194-195.

\section{Figures}




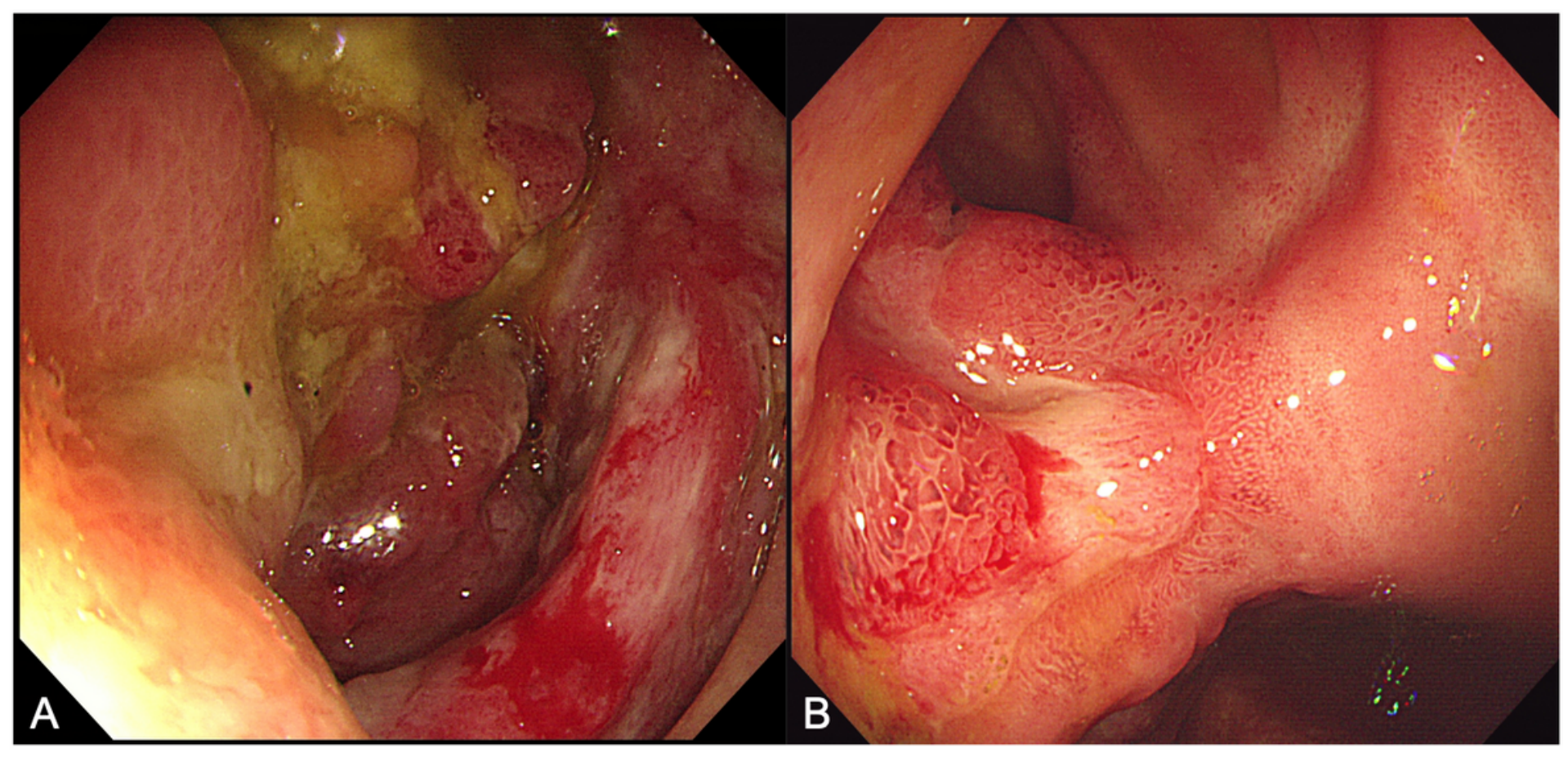

\section{Figure 1}

In two BS patients with trisomy 8, typical colonoscopy results of gastrointestinal involvement showed severe open ulcers in the ileocecal area (A), huge round edema at the end of the ileum, deep layer and diffuse erosion ulcer (B). 